\title{
A Pesticide Biopurification System: A Source of Biosurfactant-Producing Bacteria with Environmental Biotechnology Applications
}

\author{
Claudio Lamilla ${ }^{1,2}{ }^{\oplus}$, Heidi Schalchli ${ }^{2, *} \oplus$, Gabriela Briceño ${ }^{2}\left(\mathbb{D}\right.$, Bárbara Leiva ${ }^{2}$, Pamela Donoso-Piñol ${ }^{2}$, \\ Leticia Barrientos $^{3}\left(\mathbb{D}\right.$, Vanessa A. L. Rocha ${ }^{4}(\mathbb{D})$, Denise M. G. Freire ${ }^{4}$ and M. Cristina Diez ${ }^{1,2, *(\mathbb{D})}$ \\ 1 Chemical Engineering Department, University of La Frontera, Av. Francisco Salazar 01145, \\ Temuco 4780000, Chile; claudio.lamilla@ufrontera.cl \\ 2 Biotechnological Research Center Applied to the Environment (CIBAMA-BIOREN), University of La \\ Frontera, Av. Alemania 0458, Temuco 4780000, Chile; gabriela.briceno@ufrontera.cl (G.B.); \\ barbara.leiva@ufrontera.cl (B.L.); p.donoso01@ufromail.cl (P.D.-P.) \\ 3 Center of Excellence in Translational Medicine, Laboratory of Applied Molecular Biology, University of La \\ Frontera, Av. Francisco Salazar 01145, Temuco 4780000, Chile; leticia.barrientos@ufrontera.cl \\ 4 Biochemical Department, Chemistry Institute, Federal University of Rio de Janeiro, \\ Rio de Janeiro 20000-000, Brazil; vanessa.alr@gmail.com (V.A.L.R.); freire@iq.ufrj.br (D.M.G.F.) \\ * Correspondence: heidi.schalchli@ufrontera.cl (H.S.); cristina.diez@ufrontera.cl (M.C.D.)
}

Citation: Lamilla, C.; Schalchli, H.; Briceño, G.; Leiva, B.; Donoso-Piñol, P.; Barrientos, L.; Rocha, V.A.L.; Freire, D.M.G.; Diez, M.C. A Pesticide Biopurification System: A Source of Biosurfactant-Producing Bacteria with Environmental Biotechnology Applications. Agronomy 2021, 11, 624. https://doi.org/10.3390/ agronomy11040624

Academic Editors: Esperanza Romero Taboada and Rogelio Nogales Vargas-Machuca

Received: 28 February 2021

Accepted: 13 March 2021

Published: 25 March 2021

Publisher's Note: MDPI stays neutral with regard to jurisdictional claims in published maps and institutional affiliations.

Copyright: () 2021 by the authors. Licensee MDPI, Basel, Switzerland. This article is an open access article distributed under the terms and conditions of the Creative Commons Attribution (CC BY) license (https:// creativecommons.org/licenses/by/ $4.0 /)$.
Abstract: Biosurfactants, a wide group of compounds produced by different microorganisms, generally have less toxicity and are more biodegradable than synthetic surfactants. Biosurfactant-producing bacteria can be found in contaminated environments, such as soils receiving pesticide applications constantly, or in pesticides treatment systems where microorganisms are adapted to biodegrading pesticides. Five pesticide-tolerant bacteria previously isolated from a pesticide biopurification system were evaluated as biosurfactant-producers. Pseudomonas rhodesiae C4, Rhodococcus jialingiae C8 and Pseudomonas marginalis C9 strains were positive in qualitative tests. Biosurfactant production by these strains using Bushnell-Haas medium with olive oil at $2 \%(w / v)$ was evaluated as emulsification index, oil displacement, droplet collapse test and surface tension. After $144 \mathrm{~h}$, these strains showed a similar emulsification index of $>55 \%$. The two Pseudomonas (C4 and C9) strains showed lower superficial tension compared with Rhodococcus strain (C8)-34.47, 37.44 and $47.55 \mathrm{mN} / \mathrm{m}$ for strains C4, C9 and C8, respectively. The chemical characterization of the biosurfactants revealed the presence of glycolipids in P. rhodesiae (C4) and glycopeptides in P. marginalis (C9). The degradation of chlorpyrifos increased from $39.2 \%$ to $51.6 \%$ when biosurfactants produced by P. rhodesiae (C4) were added $(10 \%)$ with respect to the control. Therefore, biopurification systems are a relevant source of biosurfactant-producing bacteria with environmental biotechnology applications.

Keywords: biosurfactant-producing bacteria; biopurification system; biosurfactant characterization; chlorpyrifos degradation

\section{Introduction}

Biosurfactants are a broad group of diverse compounds produced by various microorganisms that have low toxicity, great biodegradability and environmental compatibility, enabling a wide range of industrial applications [1-3]. These compounds each have a hydrophilic region formed by amino acids-peptides (anions or cations), or mono and polysaccharides - in addition to a hydrophobic region consisting of saturated and unsaturated fatty acids [4]. The above characteristics allow for reductions in surface tension and interfacing between two immiscible liquids, increasing the solubility of hydrophobic compounds in aqueous media, forming emulsions [5]. Desorption or solubilization of hydrophobic pollutants tightly bound to soil particles can be accelerated by biosurfactants, which are very crucial for bioremediation processes, especially enhancing the degradation 
of pesticides when they are accumulated in agricultural soils [6-8]. The efficacy of biosurfactants is due to the solubilization capacity of the hydrophobic pesticides, which reduces the surface tension and interfacial bonding between liquids, solids and gases. Diverse microorganisms have been reported to be biosurfactant producers [5-8].

Wattanaphun et al. [8] highlighted a biosurfactant-producing species of Burkholderia isolated from oil-contaminated soil that may be a potential candidate for the bioremediation of a variety of pesticide contaminations. Pesticide biodegradation supported by rhamnolipids from Pseudomonas aeruginosa for the herbicide trifluralin [9] and rhamnolipid for chlorpyrifos (CHL) degradation in a soil-water system [7] have also been studied. The solubilization of endosulfan and methyl parathion supported by anionic glycolipid from Pseudomonas sp. was also studied by García et al. [10]. Singh et al. [7] reported the addition of rhamnolipid (10-200 $\mathrm{mg} \mathrm{L}^{-1}$ ) to facilitate the solubilization of CHL in soil and demonstrated that its solubility in the aqueous phase of CHL increased 2-15 times. Therefore, the authors found more $\mathrm{CHL}$ degradation (30\%) compared to the biotic control without biosurfactant. They also concluded that the addition of biosurfactants significantly improved the rate of CHL degradation in soil without accumulation of the intermediate metabolites.

One of the first reports about the improvement of CHL degradation in the presence of biosurfactants from Pseudomonas isolated from CHL-enriched soil was produced by Singh et al. [11]. The authors indicated that more than $98 \%$ degradation of CHL was obtained by the addition of $100 \mathrm{mg} \mathrm{L}^{-1}$ of partially purified rhamnolipids; the control without biosurfactants showed $84 \%$ degradation.

Even though pesticides play important roles in farming and food production worldwide, their excessive use can adversely affect the ecosystem due to their high toxicity, their persistence for variable periods and the inadequate management of pesticide residues [12]. After their applications in agriculture, pesticides may be transported off field into surface water and infiltrate groundwater, and therefore affect water quality [13], or they may penetrate wastewater generated by agro-industrial activities such as the fruit-packaging industry, which represents a disposal problem for many farmers [14,15]. Some of these pesticides, such as $\mathrm{CHL}$, are applied worldwide with relatively high chemical and biological stability in soils and aquifers $[16,17]$. CHL is an insecticide with hydrophobic character (log Kow 4.7) that is non-mobile, has low solubility in water $\left(1.4 \mathrm{mg} \mathrm{L}^{-1}\right)$ and has a variable half-life of 7-60 days depending on environmental conditions $[18,19]$. The low aqueous solubility of $\mathrm{CHL}$ further limits its availability to potential microbial degraders, which slows down the overall degradation process and becomes a major cause of CHL accumulation in soil. Moreover, 3,5,6-trichlo-2-pyridinol (TCP) has been reported to be a potent toxin of bacterial metabolism, which significantly restricts the mineralization of $\mathrm{CHL}$, leading to the accumulation of both CHL and TCP in the environment [7]. Therefore, the implementation of an efficient method for treating pesticides-contaminated water is essential to avoid their negative impact.

Pesticides, including CHL and its metabolites, can be degraded efficiently in a biopurification system (BPS) based on the adsorption and degradation capacity of an organic biomixture containing a great variety of active microorganisms, mainly fungi and bacteria $[18,20-23]$. Recently, Briceño et al. [20] showed that pesticide-tolerant bacteria isolated from the BPS have the ability to degrade different iprodione (IPR) and CHL concentrations (10 to $100 \mathrm{mg} \mathrm{L}^{-1}$ ) in liquid culture. However, the degradation of CHL was slower and less prevalent than the degradation of IPR in the same conditions; the CHL half-life $\left(t_{1 / 2}\right)$ remained elevated. It is necessary to improve their degradation capacity.

The use of synthetic surfactants in conjunction with fungicides, insecticides and herbicides can be highlighted, which increases the efficacy of pesticides for pest control [24]. However, these compounds can remain in soils, increasing environmental contamination. In the last two decades, biodegradation of pesticides by microorganisms that produce biosurfactants has been studied because it can improve the solubility of these toxic hydrophobic contaminants and make them bioavailable $[1,6,10,11,25,26]$. Biosurfactants act as emulsifying, dispersing and wetting agents $[27,28]$. Biosurfactants have also been reported 
to have some antimicrobial properties in the soil, which can affect pollutant-degrading microorganisms [29]. For this reason, the application of biosurfactants to improve the solubilization of pesticides in a BPS needs to be carefully studied in order to ensure that they do not affect the microbiota of the system. One alternative is the use of pesticide-tolerant microorganisms able to produce biosurfactants. There are reports on pesticide biodegradation supported by surfactin [9], a rhamnolipid from a bacterial consortium for CHL degradation [7]; the solubilization of chlorinated hydrocarbon [30]; and ethyl parathion, trifluralin and methyl parathion [31] supported by glycolipids. In general, ecological niches contaminated with hydrocarbon are the most recommended sites for the isolation of biosurfactant-producing microbes for environmental remediation [24]. However, studies on the production of biosurfactants by pesticide-degrading microorganisms isolated from BPS are needed to improve the effectivity of this system where high concentrations of pesticides are treated. Therefore, the aim of this study was to select biosurfactant-producing bacteria previously isolated from a pesticide BPS, evaluate their production capacity, partially characterize the crude extract in terms of biosurfactants and evaluate their effect on the degradation of the insecticide CHL.

\section{Materials and Methods}

\subsection{Chemicals and Media}

Analytical standards (99\% purity) of chlorpyrifos (CHL) and 3,5,6-trichlo-2-pyridinol (TCP) were purchased from Sigma-Aldrich (St. Louis, MO, USA) and used for highperformance liquid chromatography (HPLC) analyses. For degradation assays, formulated commercial CHL (Troya 4EC) was purchased from Agan Chemicals Manufacturers Ltd. CHL was prepared in a stock solution of $1000 \mathrm{mg} \mathrm{L}^{-1}$ in methanol, filtered through a 0.22-mm polytetrafluoroethylene (PTFE) filter and then stored at $4{ }^{\circ} \mathrm{C}$ until use. BushnellHaas $(\mathrm{BH})$ broth (Becton, Dickinson and Company, Sparks, NV, USA) and other chemicals and culture media were purchased from Difco (Detroit, Mich.), and all solvents were HPLC grade from Merck-Sigma (St. Louis, MO, USA). BH medium contained per liter: dipotassium phosphate $1.00 \mathrm{~g}$; monopotassium phosphate, $1.00 \mathrm{~g}$; ammonium nitrate, $1.00 \mathrm{~g}$; magnesium sulphate, $0.20 \mathrm{~g}$; calcium chloride, $0.02 \mathrm{~g}$ and ferric chloride, $0.05 \mathrm{~g}$. Luria-Bertani (LB) medium contains per liter: tryptone, $10 \mathrm{~g}$; yeast extract, $5 \mathrm{~g}$; NaCl, $10 \mathrm{~g}$; agar, $20 \mathrm{~g}$; pH adjusted to 7.0.

\subsection{Biosurfactant-Producing Bacteria}

The bacteria Pseudomonas rhodesiae strain C4, Achromobacter deleyi strain C7, Rhodococcus jialingiae strain C8, Pseudomonas marginalis strain C9 and Achromobacter kerstersii strain C10 were tested for biosurfactant production. These strains were previously isolated from a BPS used for pesticide treatment, identified by molecular analysis and identified as pesticidetolerant bacteria [20]. Before the biosurfactant assays, all bacterial strains were reactivated by taking an inoculum from the cryovial sown in solid Luria-Bertani (LB) medium and incubated for $24 \mathrm{~h}$ at $28 \pm 2{ }^{\circ} \mathrm{C}$. This culture procedure using liquid LB medium (without agar) was also used as the standard inoculum preparation for all experiments.

\subsection{Selection of Biosurfactant-Producing Bacteria}

The five bacterial strains were evaluated for their biosurfactant production by using Siegmund and Wagner (SW) agar and Bushnell-Haas (BH) broth. The SW blue agarcontaining cetyltrimethylammonium bromide (CTAB) plates were inoculated with $10 \mu \mathrm{L}$ broth spot-incubated bacterial strain cultures and incubated for $72 \mathrm{~h}$ at $28 \pm 2{ }^{\circ} \mathrm{C}$. Dark blue halos around the bacterial colonies were considered positive for anionic biosurfactant production [32]. The $\mathrm{BH}$ broth medium was used to evaluate the biosurfactant production as well. Briefly, $250 \mathrm{~mL}$ flasks containing $100 \mathrm{~mL}$ of $\mathrm{BH}$ culture medium were enriched with olive oil as the carbon source at a concentration of $2 \%(w / v)$ and autoclaved for $15 \mathrm{~min}$ at $121{ }^{\circ} \mathrm{C}$. The flasks were inoculated with $1 \%(v / v)$ of the bacterial strains and incubated at $28 \pm 2{ }^{\circ} \mathrm{C}$ in a shaker at $150 \mathrm{rpm}$. The production of biosurfactants was verified after $144 \mathrm{~h}$ 
of incubation in the cell-free supernatants (CFS) (centrifugation at 10,000 rpm for $15 \mathrm{~min}$ at $4{ }^{\circ} \mathrm{C}$; oil film elimination by capillary suction) by oil displacement, collapse of the drop and emulsification tests.

The positive control was the commercial Tween 80 and the negative control was Escherichia coli (non-biosurfactant producer) grown in $\mathrm{BH}$ medium. The bacterial strains that exerted the highest biosurfactant production were selected for further analyses.

\subsection{Biosurfactant Production by Selected Strains}

Strains with positive responses in SW and BH medium were used for biosurfactant production. The same conditions described above for biosurfactant production using the Bushnell-Haas $(\mathrm{BH})$ broth were used for the kinetics assay. The production of biosurfactants was verified each $24 \mathrm{~h}$ in the CFS by oil displacement and emulsification index. The measurement of surface tension was performed after $144 \mathrm{~h}$ of incubation. The validity of the surface tension readings was checked with pure water $(72.2 \pm 0.02)$ before each reading. For biomass growth quantification, samples of $2.5 \mathrm{~mL}$ were collected daily, and their absorbance values were measured at $600 \mathrm{~nm}$ in a UV-Visible spectrophotometer (Orion AquaMate 8000, Chelmsford, MA, USA).

\subsection{Oil Displacement and Emulsification Assays}

The CFS of the bacteria P. rhodesiae strain C4, R. jialingiae strain C8 and P. marginalis strain C9 obtained from 2.4 assay after $144 \mathrm{~h}$ of incubation were selected for testing their oil displacement and emulsification indices using different oils (olive, sunflower, corn, canola, grapeseed, coconut and synthetic engine oil). The oil displacement assay was performed as described by [33]. Briefly, a film of each oil $(15 \mu \mathrm{L})$ was placed over the surface of $40 \mathrm{~mL}$ distilled water in a Petri dish (15-cm diameter). Then, the clear zone of oil displacement was visualized after the addition of $10 \mu \mathrm{L}$ of CFS to the center of the oil film. Tween 80 was used as a positive control. The results are expressed as the diameter $(\mathrm{cm})$ of the displacement of the halo obtained after $3 \mathrm{~s}$. For the emulsification assay, samples ( $4 \mathrm{~mL}$ ) of each CFS were collected and mixed separately with $4 \mathrm{~mL}$ of different oils (olive, sunflower, corn, canola, grapeseed, coconut and synthetic engine oil) in a 10-mL glass tube. After addition, the solutions were vortex mixed for $4 \mathrm{~min}$ and then allowed to stand for the next $24 \mathrm{~h}$ at room temperature, except for the coconut oil, which was kept at $28 \pm 2{ }^{\circ} \mathrm{C}$. The emulsification activity was expressed as the percentage of the emulsion layer height $(\mathrm{cm})$ divided by the total of the liquid column height after $24 \mathrm{~h}$. The supernatant from each bacterial strain was evaluated, and the emulsification index (E24) was calculated using the following equation:

$$
\mathrm{E} 24(\%)=\mathrm{HE} / \mathrm{Hs} \times 100 \%
$$

where HE is the height of the emulsion layer and Hs is the height of the total solution.

\subsection{Biosurfactant Characterization}

For the crude biosurfactant extracts (CBE), the most promising bacteria (P. rhodesiae strain $\mathrm{C} 4$ and $P$. marginalis strain $C 9)$ that showed the lowest superficial tension were cultured in $\mathrm{BH}$ medium enriched with olive oil at a concentration of $2 \%(w / v)$ in the same conditions described above. The CBE were recovered using an acid precipitation and the solvent extraction method according to [34], with slight modifications. After $144 \mathrm{~h}$ of incubation, the cells were removed from the culture broth by centrifugation at $9000 \mathrm{rpm}$ for $10 \mathrm{~min}$ at $4{ }^{\circ} \mathrm{C}$. The CFS were acidified with $\mathrm{HCl} 6 \mathrm{~N}$ until the $\mathrm{pH}$ was 2 , stored overnight at $4{ }^{\circ} \mathrm{C}$ and extracted five times with ethyl acetate by using a separatory funnel. The organic phase was recovered, and the solvent was evaporated at $68^{\circ} \mathrm{C}$ in a rotary vacuum evaporator and then lyophilized. The chemical characterization of the obtained CBE was then carried out by thin layer chromatography (TLC), Fourier transform infrared spectroscopy (FTIR) and matrix-assisted laser desorption/ionization mass spectrometry analysis (MALDI TOF-TOF). 


\subsubsection{TLC}

The TLC plates were used for partial purification of surfactant biomolecules with silica gel (Silica gel 60 F254; Merck, Germany) as the stationary phase. A quantity of the BCE $(0.1 \mathrm{~g})$ dissolved in methanol was put on a TLC plate. A mixture of chloroform:methanol:acetic acid $(65: 15: 2 v / v)$ was used as the mobile phase, and detection was performed by exposure to iodine vapors for lipid stains, exposure by spraying $50 \%(v / v)$ $\mathrm{H}_{2} \mathrm{SO}_{4}$ for carbohydrate detection and exposure to $2 \%$ ninhydrin solution for amino acid detection. TLC plates were heated at $110^{\circ} \mathrm{C}$ until the appearance of the respective colors.

\subsubsection{FTIR Spectroscopy}

About $2 \mathrm{mg}$ of freeze-dried extract was milled with $200 \mathrm{mg}$ of $\mathrm{KBr}$. This powder was compressed into a thin pellet which could be analyzed by FTIR spectra measuring the transmittance between the frequencies of 4000 to $400 \mathrm{~cm}^{-1}$ with a resolution of $2 \mathrm{~cm}^{-1}$ [2].

\subsubsection{MALDI TOF-TOF Analysis}

An aliquot $(0.5 \mu \mathrm{L})$ of each purified biosurfactant (from C4 and C9 strains) was placed in the anchor chip position on a plate, and $0.5 \mu \mathrm{L}$ of the matrix was added to the sample purification point. The matrix was a saturated solution of 2.5-dihydroxybenzoic acid in water and $0.3 \mathrm{mg} \mathrm{mL}^{-1} \alpha$-cyano-4-hydroxycinnamic acid in acetone:ethanol $(2: 1 v / v)$. Mass spectra were obtained using a MALDI TOF-TOF Autoflex Speed (Bruker Daltonics, Bremen, Germany) equipped with a smart beam laser source $(334 \mathrm{~nm})$. The analyses were performed in the linear mode with positive polarity, $20 \mathrm{kV}$ accelerating voltage and a delay extraction of $220 \mathrm{~ns}$. Each spectrum was collected as an average of 1200 laser shots with enough energy to produce good unsaturated spectra in the m/z range of 1000 to 2000 . Before the analysis, the equipment was externally calibrated with the protein calibration standard I (Bruker Daltonics, Bremen, Germany) (insulin, ubiquitin, cytochrome $\mathrm{C}$ and myoglobin) with the FlexControl 1.4 (Bruker Daltonics, Bremen, Germany).

\subsection{Biosurfactants Analyses}

\subsubsection{Drop-Collapse Test}

The ability to collapse a droplet of water was tested as described by [35], with some modifications. An aliquot of $25 \mu \mathrm{L}$ of CFS of each sample was pipetted as a droplet onto Parafilm "M" laboratory film (American National Can, Chicago, IL, USA). The flattening and spreading of the droplet on the parafilm surface were followed over seconds. Subsequently, Methylene Blue was added to stain the drop of supernatants and a drop of water as the control.

\subsubsection{Surface Tension Assay}

The surface tension was measured according to Song and Springer (1996) for the CFS that were obtained by centrifugation of the culture medium after $144 \mathrm{~h}$ of incubation under the conditions described above using a Krüss Easy Dyne tensiometer (Hamburg, Germany) at room temperature, following the principle of the Wilhelmy plate method.

\subsubsection{Oil Displacement and Emulsification Analyses}

The analysis of these parameters was performed following the methodology described in Section 2.5 but using olive oil as the sole oil type.

\subsection{Chlorpyrifos Degradation by Biosurfactant-Producing Bacteria}

To evaluate the effect of biosurfactant addition in CHL degradation, the assay was conducted in 250-mL Erlenmeyer flasks containing $100 \mathrm{~mL}$ of sterile liquid LB medium supplemented with CHL at $25 \mathrm{mg} \mathrm{L}^{-1}$. This concentration is about 15 times over CHL's solubility (1.4 $\mathrm{mg} \mathrm{L}^{-1}$ in water). Flasks were inoculated with $1 \%(v / v)$ of the P. rhodesiae strain $\mathrm{C} 4$ - previously centrifuged, washed and resuspended in $0.9 \% \mathrm{NaCl}$. Then, an aliquot of $10 \mathrm{~mL}$ of the CFS of the C4 strain obtained as described in Section 2.3 was added 
at $2.5 \%, 5.0 \%, 7.5 \%$ and $10 \%$ of the total volume of each flask. The biotic control contained CHL and P. rhodesiae strain C4 without CFS, and the abiotic control contained CHL and CFS (5\%) without the bacterial inoculum. Afterward, the flasks were incubated at $28 \pm 2{ }^{\circ} \mathrm{C}$ on a rotary shaker for $24 \mathrm{~h}$ at $130 \mathrm{rpm}$ in the dark. Samples were taken at the end of the incubation period $(144 \mathrm{~h})$ for analysis of residual pesticide and metabolites. CHL and TCP concentrations were analyzed by HPLC. All assays were conducted in triplicate.

\subsection{Pesticide Extraction and Analysis}

Samples of $1 \mathrm{~mL}$ were taken every three hours from each flask and centrifuged for $10 \mathrm{~min}$ at $6500 \mathrm{rpm}$. Then, samples of $0.5 \mathrm{~mL}$ of the supernatant were diluted in $1 \mathrm{~mL}$ of acetonitrile. The samples were homogenized in a vortex and filtered by PTFE $0.22-\mu \mathrm{m}$ filter before analysis for CHL and TCP concentrations. The HPLC analysis was performed using a Merck Hitachi L-2130 pump equipped with a Rheodyne 7725 injector and a Merck Hitachi L-2455 diode array detector. Separation was achieved using a C18 column (Chromolit RP-8e, $4.6 \mu \mathrm{m} \times 100 \mathrm{~mm})$. The conditions for HPLC analysis were as described by Briceño et al. 2020. For CHL, the average recovery was $101 \% \pm 0.7 \%$, the limit of quantification (LOQ) was $0.214 \mathrm{mg} \mathrm{L}^{-1}$ and the limit of detection (LOD) was $0.081 \mathrm{mg} \mathrm{L}^{-1}$.

\subsection{Kinetic Calculations}

The specific growth rate $(\mu)$ of bacterial biomass for the exponential phase was calculated by the following equation:

$$
\mu \max =\frac{1}{x}\left(\frac{d x}{d t}\right)
$$

where $\mu$ is the specific growth rate $\left(\mathrm{h}^{-1}\right), x$ is the biomass concentration $\left(\mathrm{g} \mathrm{L}^{-1}\right)$ and $t$ is time (h). The CHL degradation was described using the following first-order kinetic equation:

$$
C=C_{o} \times e^{-K t}
$$

where $C$ is the concentration of the pesticide over time, $C_{o}$ is the initial concentration, $K$ is the degradation constant and $t$ is time. The pesticide half-life $\left(\mathrm{T}_{1 / 2}\right)$ is the time at which CHL concentration in the liquid medium was reduced by $50 \%$, and that was calculated using the following equation:

$$
T_{1 / 2}=\frac{\ln 2}{k}
$$

\subsection{Statistical Analyses}

Determinations were carried out in triplicate and the results are expressed as average values. One-way ANOVA (Tukey test, $p \leq 0.05$ ) was employed to compare treatments, and the Pearson's correlation coefficient method was used to determine correlation between each emulsification index and the respective oil displacement data. Statistical analyses were performed using the statistical software GraphPad Prism.

\section{Results}

\subsection{Selection of Biosurfactant-Producing Bacteria}

The results of the pesticide-tolerant bacterial strains tested as potential producers of biosurfactants in SW and $\mathrm{BH}$ media are shown in Table 1. The bacteria P. rhodesiae strain C4, R. jialingiae strain C8 and P. marginalis strain C9 were positive in SW agar, confirming the presence of biosurfactants by the formation of blue halos around the colonies. Those three strains presented the highest olive oil displacement $(\geq 13 \mathrm{~cm})$, were positive in the drop-collapse test and presented a high emulsification index $(\geq 49 \%)$. The bacteria $A$. deley $i$ strain $\mathrm{C} 7$ and $A$. kerstersii strain $\mathrm{C} 10$ were negative with respect to the CTAB analysis and $\mathrm{C} 10$ strain did not produce drop-collapse or olive oil displacement. Therefore, the three 
bacteria P. rhodesiae strain C4, R. jialingiae strain C8 and P. marginalis strain C9 were selected as biosurfactant producers for further assays.

Table 1. Pesticide-tolerant bacterial strains tested as potential producers of biosurfactants in Siegmund and Wagner (SW) agar and Bushnell-Haas (BH) media.

\begin{tabular}{ccccccc}
\hline $\mathbf{N}^{\circ}$ & Bacteria & Strain $\mathbf{1}^{-}$ & CTAB & $\begin{array}{c}\text { Emulsification } \\
(\mathbf{\%})\end{array}$ & $\begin{array}{c}\text { Displacement } \\
(\mathbf{c m})\end{array}$ & Drop-Collapse \\
\hline 1 & P. rhodesiae & C4 & + & 55 & $14 \pm 0.1$ & + \\
2 & A. deleyi & C7 & - & 48 & $12 \pm 1.1$ & +1.5 \\
3 & R. jialingiae & C8 & + & 54 & $14 \pm 1.2$ & + \\
4 & P. marginalis & C9 & + & 49 & $1 \pm 0.5$ & + \\
5 & A. kerstersii & C10 & - & 53 & $14 \pm 0.0$ & + \\
& Control (+) & & - & 0 & $0 \pm 0.0$ & - \\
\hline
\end{tabular}

${ }^{1}$ The tested strains were isolated and identified previously by Briceño et al. [20]. CTAB = blue agar containing cetyltrimethylammonium bromide (SW agar). $+=$ positive response, $-=$ negative response. Control $(+)=$ Tween 80 , Control $(-)=$ Escherichia coli grown in BH medium. Data of the displacement assay are given as the mean $\pm \mathrm{SD}(n=3)$.

\subsection{The Kinetics of Biosurfactant Production by the Selected Strains}

The evaluations of biomass growth and biosurfactant production by means of oil displacement, emulsification index and surface tension analysis over time were carried out in BH medium with olive oil as the carbon source. Bacterial growth is shown in Figure 1. We can observe that $P$. rhodesiae strain C4 and P. marginalis strain C9 presented similar behavior, and these bacteria begun their exponential growth phase after $24 \mathrm{~h}$ with $\mu$ max values of 0.248 and $0.294 \mathrm{~h}^{-1}$, respectively. On the other hand, $R$. jialingiae strain C8 presented low growth during the first $72 \mathrm{~h}$ and, after that, the $\mathrm{C} 8$ strain grew exponentially with a $\mu$ max value of $0.155 \mathrm{~h}^{-1}$.

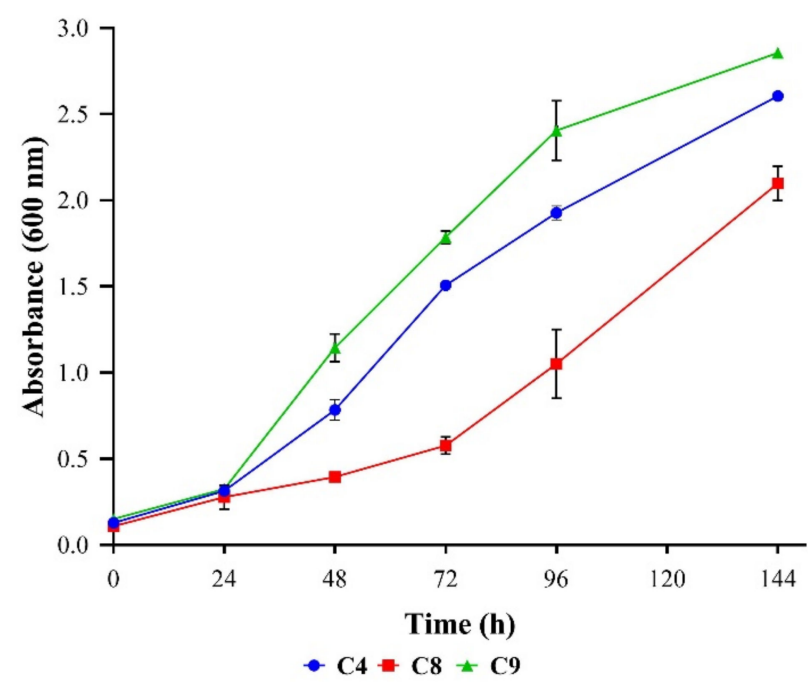

Figure 1. Bacterial growth in BH media with olive oil $(2 \% w / v)$ as a carbon source. Data are given as the mean $\pm \mathrm{SD}(n=3)$.

The production of biosurfactants, evaluated as oil displacement $(\mathrm{cm})$ of the three selected strains, is shown in Figure 2a. P. rhodesiae strain C4 started the production of biosurfactants after $24 \mathrm{~h}$, reaching its maximum at $144 \mathrm{~h}(13.8 \mathrm{~cm})$. On the other hand, P. marginalis strain C9 started production of biosurfactants before $24 \mathrm{~h}$, reaching its maximum at $120 \mathrm{~h}(13.8 \mathrm{~cm})$. R. jialingiae strain C8 begun biosurfactant production after $48 \mathrm{~h}$ and showed less production at $144 \mathrm{~h}(11.0 \mathrm{~cm})$ compared with the C4 and C9 strains. With respect to the production of biosurfactants evaluated as an emulsification index, similar behavior was observed between the strains: emulsification index raised as incubation 
time increased (Figure 2b). After $144 \mathrm{~h}$, the three strains showed similar emulsification indexes $>55 \%$. Surface tension values measured at the end of the incubation period were $34.47 \pm 0.20,47.55 \pm 0.58$ and $37.44 \pm 0.37 \mathrm{mN} / \mathrm{m}$ for $P$. rhodesiae strain C4, $R$. jialingiae strain C8 and P. marginalis strain C9, respectively.

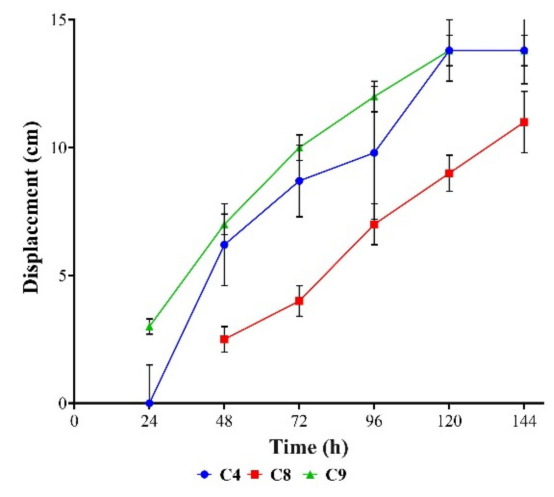

(a)

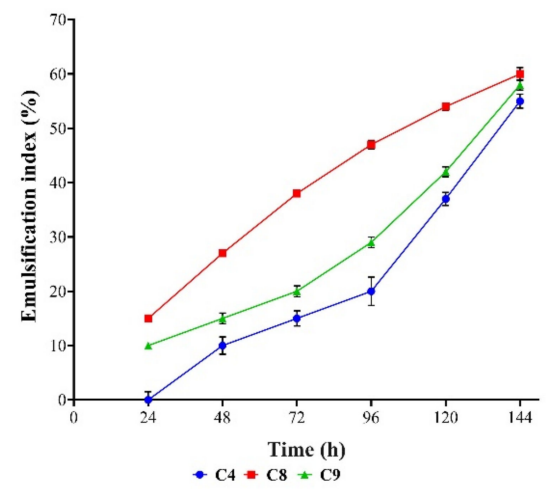

(b)

Figure 2. Biosurfactant production in $\mathrm{BH}$ media with olive oil $(2 \% w / v)$ as the carbon source. Displacement of olive oil (a) and emulsification index E24 (b). Data are given as the mean \pm SD $(n=3)$.

\subsection{Oil Displacement and Emulsification Assays}

The biosurfactant production capacities of the selected strains were evaluated as displacement and emulsification index in different types of oils (olive, sunflower, corn, canola, grapeseed, coconut and synthetic engine oil). These techniques have several advantages, since they require small volumes of sample, are quick and easy to perform, do not require specialized equipment and are economical. The emulsification index obtained with the CFS of each selected strain is shown in Figure 3a, and all were $>50 \%$, except for the CFS of $P$. rhodesiae strain C4 and R. jialingiae strain C8 $(<40 \%)$ in coconut oil. Notably, the highest emulsification index $(>80 \%)$ was obtained for synthetic engine oil. The oil displacement test is an indirect measurement of surface activity; a larger diameter indicates a higher surface activity of the testing solution [10]. The results of the oil displacement generated by the three CFS evaluated (strains C4, C8 and C9) are shown in Figure 3b. We can observe that oil displacement was high ( $>86 \%)$ except for synthetic engine oil, mainly when the CFS of $P$. rhodesiae strain C4 was tested $(\sim 40 \%)$.

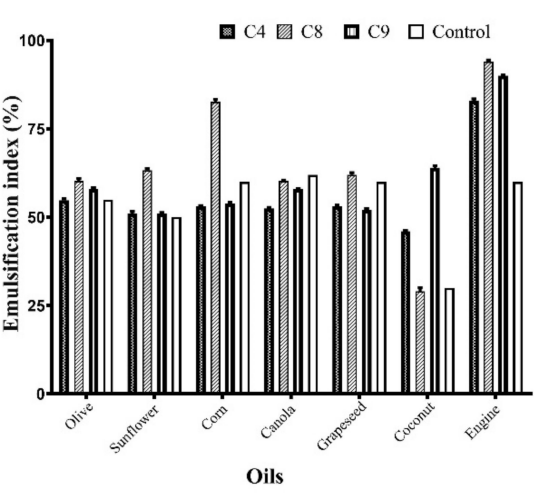

(a)

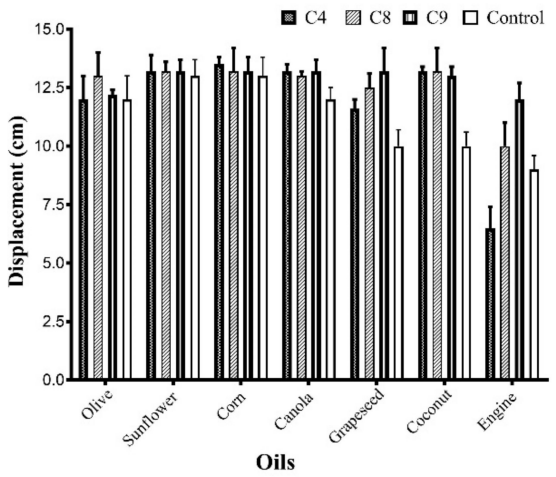

(b)

Figure 3. Emulsification index E24 (a) and oil displacement (b) produced by the cell-free supernatants (CFS) of the bacterial strains in BH medium with olive oil, against different oils. Data are given as the mean $\pm \mathrm{SD}(n=3)$. 


\subsection{Biosurfactant Characterization}

Crude extracts of biosurfactants (CEB) obtained from P. rhodesiae strain C4 and P. marginalis strain $C 9$ were selected due to their lower superficial tension compared with the CEB from $R$. jialingiae strain C8. Furthermore, $R$. jialingiae strain C8 showed the lowest $\mu$ max value and slowest biosurfactant production. The results of the chemical composition of the biosurfactants evaluated in the CBE of the selected P. rhodesiae strain C4 and $P$. marginalis strain C9 were obtained by thin layer chromatography (Figure 4). The presence of lipids in both samples was observed (Figure 4a), along with the presence of carbohydrates (Figure 4c). Additionally, the presence of proteins was observed only in the sample of P. marginalis strain C9 (Figure 4b).

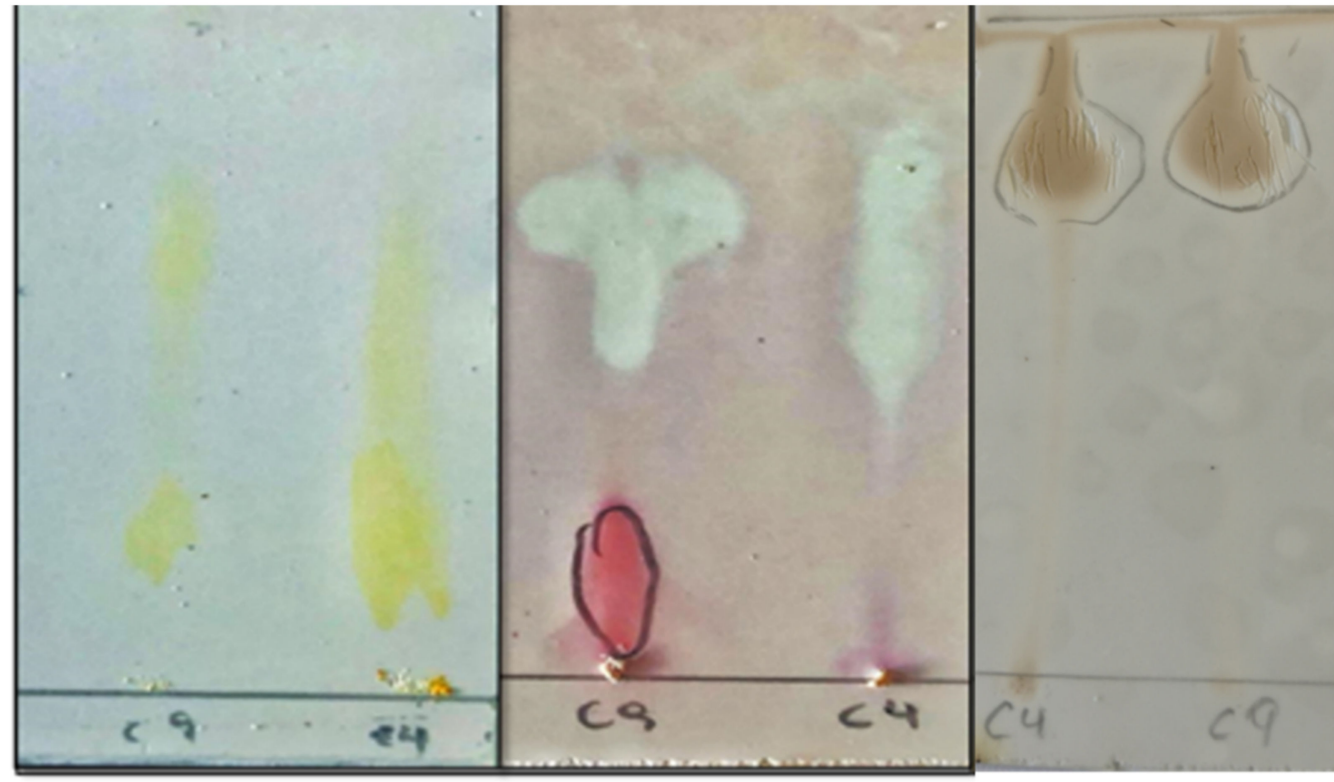

(a)

(b)

(c)

Figure 4. Thin layer chromatography (TLC) plates of purified biosurfactants of bacteria Pseudomonas rhodesiae strain C4 and Pseudomonas marginalis strain C9. Reactions with iodine (a), ninhydrin (b) and $\mathrm{H}_{2} \mathrm{SO}_{4}$ (c).

FTIR analyses of the CBE for P. rhodesiae strain C4 and P. marginalis strain C9 are shown in Figure 5a,b, respectively. The bands in the region between 1161 and $1375 \mathrm{~cm}^{-1}$ for $P$. rhodesiae strain $\mathrm{C} 4$ and 1155 and $1378 \mathrm{~cm}^{-1}$ for $P$. marginalis strain $C 9$ are the results of deformation and bending vibrations of the $-\mathrm{C}-\mathrm{CH}_{2}$ and $-\mathrm{C}^{-} \mathrm{CH}_{3}$ groups in the aliphatic chains (carbohydrates). $\mathrm{C}-\mathrm{H}$ bonds of $\mathrm{CH}_{2}$ and $\mathrm{CH}_{3}$ groups observed at $2921 \mathrm{~cm}^{-1}$ for P. rhodesiae strain C4 and $2917 \mathrm{~cm}^{-1}$ for P. marginalis strain C9 confirmed the presence of aliphatic chains. Peaks detected in the region of $2851 \mathrm{~cm}^{-1}$ for P. rhodesiae strain C4 and $2849 \mathrm{~cm}^{-1}$ for $P$. marginalis strain $\mathrm{C} 9$ showed $\mathrm{CH}$ stretching of the $\mathrm{CH}$ groups $\mathrm{CH}_{3}$ and $\mathrm{CH}_{2}$ in the alkyl chains (lipids). The presence of amino and hydroxyl groups of the protein in the P. marginalis strain C9 identified the biosurfactant type of P. marginalis strain C9 and it was observed with the combination C-O amide I $\left(1707 \mathrm{~cm}^{-1}\right)$ and $-\mathrm{NH} /-\mathrm{C}$ of the amide band II $\left(1452 \mathrm{~cm}^{-1}\right)$ [36]. 


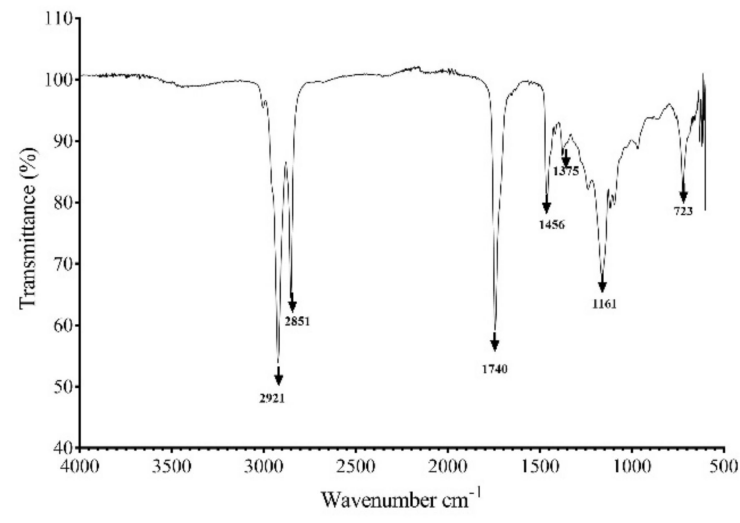

(a)

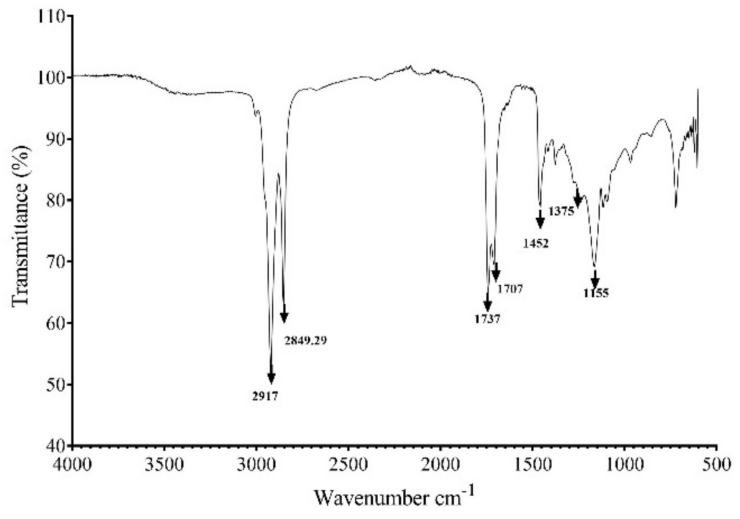

(b)

Figure 5. FTIR spectrum of the biosurfactant produced by the bacterial strains: (a) Pseudomonas rhodesiae strain C4 and (b) Pseudomonas marginalis strain C9.

The MALDI TOF-TOF mass spectrum of the CEB of the P. rhodesiae strain C4 is presented in Figure 6a. The prominent groups of mass peaks range from 1200 to $1600 \mathrm{~m} / \mathrm{z}$. The signals at m/z 1380.4 and 1218.3 correspond well to the glycolipids S-TeGD and STGD-1, respectively. Figure $6 \mathrm{~b}$ shows the MALDI TOF-TOF mass spectrum of the CEB of P. marginalis strain C9, with the most prominent peaks being 1057.11, 1102.20, 1147.49, 1192.60, 1283.123 and 1192.604, indicating the presence of proteins and lipids. Therefore, the identification of a P. marginalis strain C9 biosurfactant would correspond to a glycopeptide.

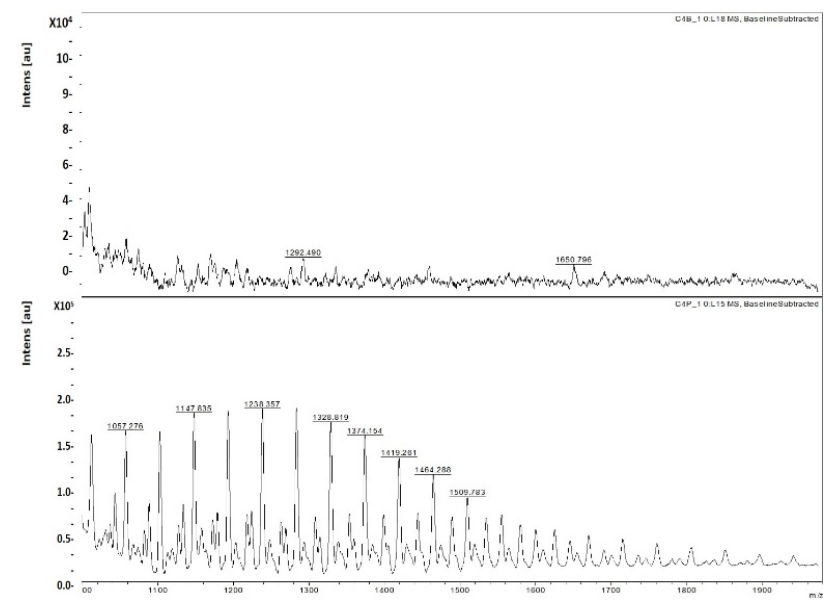

(a)

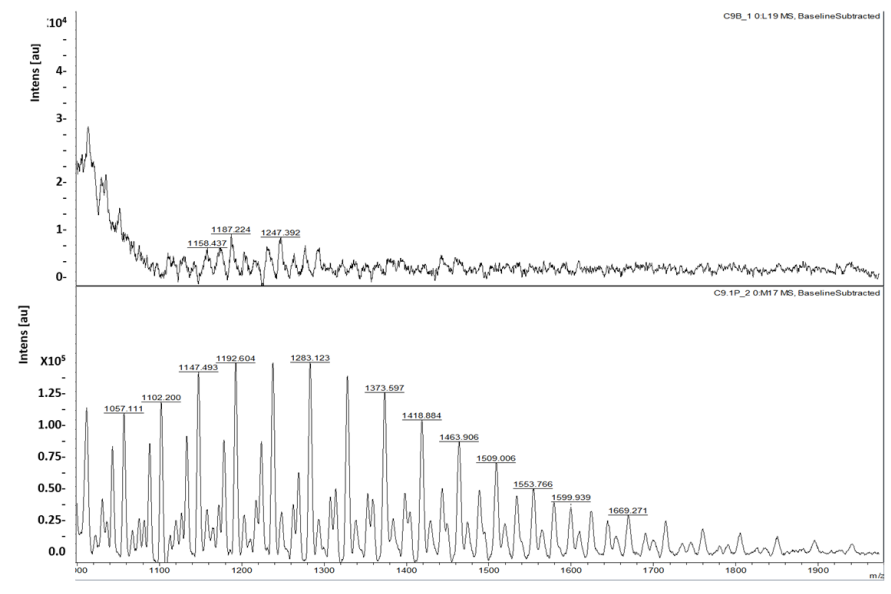

(b)

Figure 6. Mass spectrum of the crude extract biosurfactant produced by the bacterial strains: (a) Pseudomonas rhodesiae strain C4 and (b) Pseudomonas marginalis strain C9.

\subsection{Degradation of Chlorpyrifos}

The $P$. rhodesiae strain C4 demonstrated previously a moderate degradation of CHL (39\%) at an initial CHL concentration of $20 \mathrm{mg} \mathrm{L}^{-1}$, and in this study demonstrated high biosurfactant activity. CHL (50 $\left.\mathrm{mg} \mathrm{L}^{-1}\right)$ degradation increased with the addition of biosurfactants obtained from CFS of P. rhodesiae strain C4 (Table 2). The results are significantly different $(p<0.05)$ with respect to the degradation of CHL obtained in the biotic control assay without CFS addition. Degradation of CHL was high through the addition of CFS that contained biosurfactants, improving the degradation from $46.7 \%$ to $51.6 \%$ when CFS went from $2.5 \%$ to $10 \%$. The CHL degradation with respect to the biotic control increased from $15.8 \%$ to $23.8 \%$ when CFS went from $2.5 \%$ to $10 \%$. The metabolite 
TCP increased with the increment in CFS addition, varying from 0.51 to $0.896 \mathrm{mg} \mathrm{L}^{-1}$, showing an effective degradation process for CHL (Table 2).

Table 2. Degradation of CHL and formation of its metabolite 3,5,6-trichlo-2-pyridinol (TCP) in LB medium with biosurfactant addition obtained from Pseudomonas rhodesiae strain C4.

\begin{tabular}{|c|c|c|c|c|}
\hline $\begin{array}{c}\text { CFS Addition } \\
(\%)\end{array}$ & $\begin{array}{l}\text { Residual CHL } \\
\quad\left(\mathrm{mg} \mathrm{L}^{-1}\right)\end{array}$ & $\begin{array}{c}\text { Degradation } \\
(\%)\end{array}$ & $\begin{array}{c}\text { Increment * } \\
(\%)\end{array}$ & $\begin{array}{c}\text { TCP } \\
\left(\mathrm{mg} \mathrm{L}^{-1}\right)\end{array}$ \\
\hline 0 (biotic control) & $15.22 \pm 0.13$ & $39.3 c$ & 0 & $0.51 \pm 0.01$ \\
\hline 2.5 & $13.37 \pm 0.02$ & $46.7 \mathrm{a}, \mathrm{b}$ & 15.8 & $0.53 \pm 0.02$ \\
\hline 5.0 & $12.77 \pm 0.02$ & $49.1 \mathrm{a}$ & 19.9 & $0.56 \pm 0.01$ \\
\hline 7.5 & $12.46 \pm 0.05$ & $50.4 \mathrm{a}$ & 22.0 & $0.82 \pm 0.06$ \\
\hline 10 & $12.15 \pm 0.04$ & $51.6 \mathrm{a}$ & 23.8 & $0.90 \pm 0.01$ \\
\hline 5 (abiotic control) & $24.92 \pm 0.07$ & 0 & 0 & 0 \\
\hline
\end{tabular}

* The increment in CHL degradation compared with the biotic control. CFS = cell-free supernatant; $\mathrm{CHL}=$ chlorpyrifos; TCP $=3,5,6$-trichlo-2-pyridinol. Biotic control $=$ P. rhodesiae strain C4 grown in LB medium + CHL without CFS; abiotic control = LB medium + CHL without bacterial inoculum. Different letters indicate significant differences $(p<0.05)$ between treatments in degradation $(\%)$.

\section{Discussion}

Different environments have been studied to obtain specialized biosurfactant-producing microorganisms, it being possible to select different strains and to evaluate their biosurfactants for the degradation of different organic molecules. The five strains used in our study were identified in a previous study of Briceño et al. [20] as pesticide-tolerant and pesticide degrader strains, at high pesticide concentrations. It was considered likely that some of them are capable of biosurfactant production. Sixty percent of the bacterial strains tested positive on SW agar, indicating the production of extracellular ionic biosurfactants. The studied bacteria Pseudomonas spp. (strains C4 and C9) and R. jialingiae strain C8 showed adequate biosurfactant activity (Table 1). Both Pseudomonas species and the Actinobacteria belonging to Rhodococcus genus are well-known for their biosurfactant production $[10,25,37,38]$.

The kinetics of bacterial growth and biosurfactant production by the selected strains allowed us to know their behavior over time. Adequate growth of the strains in $\mathrm{BH}$ medium supplemented with olive oil $(2 \% w / v)$ was observed due to oils being used as fresh raw material for the production of biosurfactants, especially in Pseudomonas genera [39-41]. The free fatty acid contents of materials such as olive oil support the growth of microorganisms, emphasizing the stimulation of biosurfactant production by means of olive oil $[40,42,43]$. Concerning the results of surface tension, in the present study, the surface tension values obtained for the main biosurfactant-producing strains $(34.47 \mathrm{mN} / \mathrm{m}$ for P. rhodesiae strain $\mathrm{C} 4$ and $37.44 \mathrm{mN} / \mathrm{m}$ for $P$. marginalis strain C9) were very close to those described in the literature. For example, P. aeruginosa strain using $2 \%$ coconut oil produced biosurfactants with the capacity to reduce the surface tension of the medium from 45 to $31 \mathrm{mN} / \mathrm{m}$ [39]. The measurement of surface tension $(\mathrm{mN} / \mathrm{m})$ showed that the supernatants of $P$. rhodesiae strain $\mathrm{C} 4$ and $P$. marginalis strain $\mathrm{C} 9$ produce biosurfactants due to their low surface tension $(<39 \mathrm{mN} / \mathrm{m})$. On the other hand, the highest emulsification index and the lowest oil displacement of $\mathrm{C} 8$ strain (Figures 1 and 2), associated with the lowest $\mu$ max value, can be explained because strains of Rhodococcus have been reported as producers of bioemulsifiers, not just biosurfactants [44]. Such results indicated the presence of biosurfactant and bioemulsifier-producing bacteria in this study [44,45]. Biosurfactant and bioemulsifier production during the bacterial growth of $P$. rhodesiae strain C4, R. jialingiae strain C8 and P. marginalis strain C9, evaluated as displacement of olive oil and emulsification index (E24), showed a high positive correlation (Figure 7). In other words, the bioemulsifiercontaining supernatant (R. jialingiae strain $C 8$ ) had a low emulsification index and a high oil displacement, and in the supernatant samples containing the biosurfactants ( $P$. rhodesiae strain C4 and P. marginalis strain C9), there was an increase in both the emulsification index and the oil displacement. 


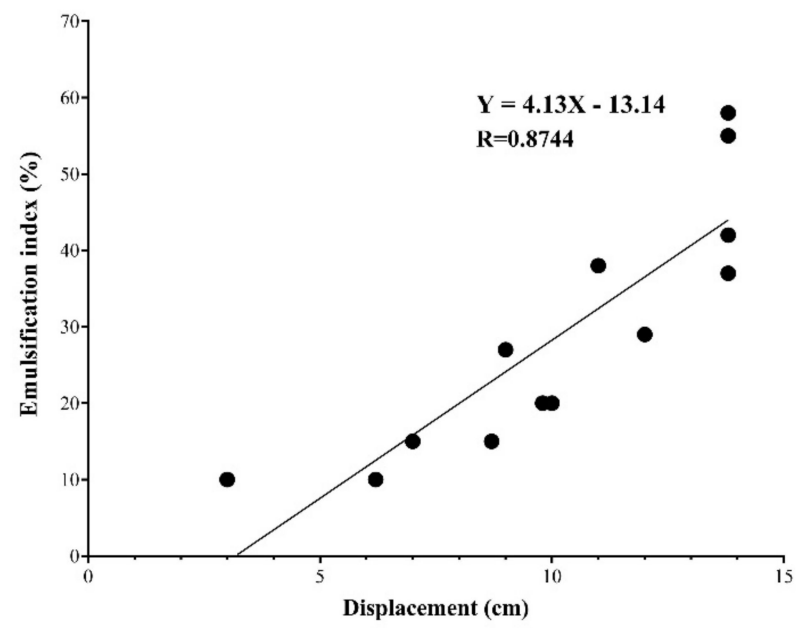

Figure 7. Correlation between emulsification index E24 and oil displacement $(\mathrm{cm})$ (each point represents the average of three replicates).

According to the literature, depending on the type of oil, the emulsification index varies. Thavasi et al. [3], for example, found that the emulsification of different hydrocarbons by biosurfactants was in the order of waste motor lubricant oil $>$ crude oil $>$ peanut oil $>$ kerosene $>$ diesel $>$ xylene $>$ naphthalene $>$ anthracene. In our study, by comparing the different vegetal oils (olive, sunflower, corn, canola, grapeseed and coconut) and a synthetic oil (engine oil), we observed that for most of the vegetal oils the emulsification indices were similar (not coconut oil or engine oil). Coconut oil was an exception because coconut oil has a high level of saturated fat, hindering its emulsification. In the case of engine oil, it is a lighter oil, and that makes its emulsification easier. However, when the emulsification index was evaluated by specifically comparing the effects of the biosurfactants from $P$. rhodesiae strain C4, R. jialingiae strain C8 and P. marginalis strain C9 on the oils and their respective controls (Tween 80 ), almost no difference was observed. This can be explained because biosurfactants are effective at forming micelles that encapsulate the oil and generate emulsions, since the lowering of surface tension facilitates emulsification of these fluids, and the ability of these different biosurfactants to emulsify distinct oils was shown. The emulsification capacities of different hydrocarbons by the biosurfactants reflect the possibility of their applications against different types of hydrocarbon pollution, including pesticides. Solubilization is the main mechanism for oil emulsification. The phenomenon of oil incorporation in micelles can be explained as follows: inside the micelles, there is a hydrophobic region where the hydrophobic moiety is linked, while outside the micelles the hydrophilic part is in an aqueous solution [46]. Therefore, as the emulsion stability increases, the oil viscosity decreases, generating better pesticide removal.

In general terms, the oil displacement showed an inverse pattern compared to the emulsification index, as expected. In other words, engine oil, which is a lighter oil, had less displacement-that is, the repulsion of biosurfactants by this oil was lower. This happens because there is a fast biosurfactant adsorption mechanism for the carboxylic acids and their anions at the oil-water interface. When biosurfactants are added to the plates, the oil is quickly adsorbed and incorporated into micelles and repelled to the edge of the plate. The heavier the oil, the greater the repulsion and the lighter the oil, the less the repulsion [46]. Moreover, the few variations observed between the oil displacements may be related to the hydrophilic/lipophilic balances of the respective oils.

TLC can estimate of the compositions of biosurfactants, due to the different types of molecules having different affinities to the mobile or the stationary phase via capillary action. Here we evaluated the affinities of the purified biosurfactants from P. rhodesiae strain $\mathrm{C} 4$ and P. marginalis strain $\mathrm{C} 9$ for iodine, ninhydrin and $\mathrm{H}_{2} \mathrm{SO}_{4}$. Our results indicate that the biosurfactant from CEB of $P$. rhodesiae strain $\mathrm{C} 4$ is probably a glycolipid, due to the presence of lipids and carbohydrates. This type of biosurfactant is commonly reported in 
Pseudomonas sp. [36]. On the other hand, P. marginalis strain C9's biosurfactant is probably a glycopeptide since, in addition to lipids and carbohydrates, it also has protein in its structure $[10,47]$.

Such TLC results are in accordance with the FTIR results. FTIR analysis showed that P. rhodesiae strain C4's biosurfactant contained aliphatic chains (carbohydrates) and alkyl chains (lipids). The observed IR pattern of this biosurfactant was very similar to the IR spectrum of the glycolipid biosurfactants produced by Pseudomonas sp. reported by Thavasi and co-authors [39], which was indicated to remediate different forms of hydrocarbon pollution. According to García et al. [10], pesticide biodegradation is hindered due to the low solubility in water of these hydrophobic molecules, causing low bioavailability. A way to improve pesticide availability and degradability is the use of biosurfactants as additives to increase the pesticide's aqueous solubility. Additionally, this work related that Pseudomonas sp. biosurfactants were adequate to enhance the solubility of pesticides. In parallel, FTIR analysis of P. marginalis strain C9's biosurfactant revealed that its composition included aliphatic chains (carbohydrates), alkyl chains (lipids) and, surprisingly, proteins. This probable glycopeptide from Pseudomonas should be better studied to understand its structure. However, our study has shown its capacity for applications with pesticide. Indeed, biosurfactants from both strains ( $P$. rhodesiae strain $C 4$ and $P$. marginalis strain C9) presented great ability for oil emulsification and oil displacement, suggesting their potential use as pesticide additives.

Complementarily, MALDI TOF-TOF mass spectra of the CEB of the P. rhodesiae strain C4 revealed the prominent groups of mass peaks (1200 to $1600 \mathrm{~m} / \mathrm{z}$ ) showing similarity to those previously reported for the glycolipid complexes in MALDI TOF-TOF MS [48]. The signals at m/z 1380.4 and 1218.3 correspond well to the glycolipids S-TeGD and STGD-1, respectively, and are similar to those reported by Angelini et al. [49]. On the other hand, the MALDI TOF-TOF mass spectrum of the CEB of P. marginalis strain C9 showed the most prominent peaks, at 1057.11, 1102.20, 1147.49, 1192.60, 1283.123 and 1192.604, indicating the presence of protein and lipid. Therefore, the identification attempts for our Pseudomonas-isolated biosurfactant via FTIR and MALDI TOF-TOF indicate glycolipids and glycopeptides, respectively, and both have been frequently identified in the genus Pseudomonas [10,38].

Microorganisms are capable of degrading high concentrations of hydrophobic pesticides in adequate environmental conditions, such as in BPS, where adsorption and degradation processes occur in an organic biomixture $[14,18,21,22,50]$. These microorganisms, bacteria and fungi, have pools of enzymes, including ligninolytic enzymes capable of pesticide degradation $[18,19,23,50-52]$. Screening for degrading microorganisms in a pesticide-contaminated system allows for the selection of potential isolates with a high tolerance and maximal degrading activity [53]. Recently, Briceño et al. [20] isolated, characterized and identified pesticide-tolerant bacteria from a biomixture of a BPS that had received continuous applications of a pesticide mixture, and demonstrated adequate degradation of CHL (39\%) at an initial CHL concentration of $20 \mathrm{mg} \mathrm{L}^{-1}$, using the C4 strain. However, the degradation took place slowly compared with the degradation of IPR. Pseudomonas strains are recognized as biosurfactant producers [7,11,25]. In our study, P. rhodesiae strain C4 demonstrated, besides its CHL degradation capacity, glycolipid-type biosurfactant production-CHL degradation increased as the CEB concentration increased (15.8\% to $23.8 \%$ ). This increment, due the biosurfactant's addition, is especially important for highly hydrophobic CHL pesticide degradation $[7,11]$. However, the high pesticide concentration could limit the proliferation of some degrading microorganisms, specifically during the CHL degradation due to the production of the metabolite TCP, which is recognized by its antimicrobial properties [7]. In our study, TCP production was observed during CHL degradation with $P$. rhodesiae strain $\mathrm{C} 4$ and increased as the quantity of CEB rose, with the maximum value of $0.896 \mathrm{mg} \mathrm{L}^{-1}$. Pseudomonas spp. has been commonly described as a CHL degrader [54]. Despite the fact that most pesticide-degrading microorganisms have been isolated from soil with a history of pesticide application [55], the biomixture of the BPS was 
an appropriate ecosystem to obtain pesticide-tolerant bacteria with biosurfactant activity. Therefore, the use of biosurfactants is promising for the remediation of contaminated sites and for the biotechnological treatment of pesticide residues in bioremediation processes.

\section{Conclusions}

This study demonstrated that bacteria isolated from a biopurification system have the ability to produce extracellular active biosurfactant biomolecules. Three of the five strains showed the ability to produce biosurfactants in $\mathrm{BH}$ culture media supplemented with olive oil as a carbon source. Two of them belonged to the genus Pseudomonas and one to Rhodococcus. The biosurfactants produced in the three strains had the ability to emulsify and displace different oils and hydrocarbons at high levels. The study of surface tension showed that Pseudomonas generates biosurfactants, while Rhodococcus makes a bioemulsifier. Furthermore, the chemical characterization of the biosurfactants revealed the presence of glycolipids in CFS from P. rhodesiae strain C4 and glycopeptides in CFS from P. marginalis strain C9. Both types of biosurfactants could contribute to the degradation processes of pesticides in a biopurification system. The cell-free supernatant produced by P. rhodesiae strain C4 increased the degradation of the insecticide chlorpyrifos by about $24 \%$. Therefore, extracellular compounds produced by strains isolated from a biopurification system are rich in biosurfactants that could be used as alternatives in the bioremediation process of sites contaminated by pesticides, and this opens up the possibility of using these biosurfactants in certain biotechnological or industrial processes. Further research is needed to obtain precise elucidations of the molecular structures, which could subsequently allow quantitative determinations of the productivity and optimization of the strains' culture conditions.

Author Contributions: Conceptualization, M.C.D., C.L. and H.S.; methodology, M.C.D., L.B. and C.L.; software, C.L.; validation, G.B.; formal analysis, M.C.D. and C.L.; investigation, C.L., P.D.-P. and B.L.; resources, M.C.D.; data curation, L.B.; writing-original draft preparation, H.S. and M.C.D.; writing-review and editing, H.S. and V.A.L.R.; visualization, D.M.G.F.; supervision, M.C.D.; project administration, B.L.; funding acquisition, M.C.D. All authors have read and agreed to the published version of the manuscript.

Funding: This research was funded by ANID grant number ANID/FONDAP/15130015; ANID postdoctoral grant number FONDECYT 3190918; and DIUFRO grant numbers DI20-2013 and GAP DI20-3005.

Institutional Review Board Statement: Not applicable.

Informed Consent Statement: Not applicable.

Data Availability Statement: Data sharing not applicable.

Conflicts of Interest: The authors declare no conflict of interest.

\section{References}

1. Chaprão, M.J.; Ferreira, I.N.S.; Correa, P.F.; Rufino, R.D.; Luna, J.M.; Silva, E.J.; Sarubbo, L.A. Application of bacterial and yeast biosurfactants for enhanced removal and biodegradation of motor oil from contaminated sand. Electron. J. Biotechnol. 2015, 18, 471-479. [CrossRef]

2. Lotfabad, T.B.; Shourian, M.; Roostaazad, R.; Najafabadi, A.R.; Adelzadeh, M.R.; Noghabi, K.A. An efficient biosurfactantproducing bacterium Pseudomonas aeruginosa MR01, isolated from oil excavation areas in south of Iran. Colloids Surf. B Biointerfaces 2009, 69, 183-193. [CrossRef] [PubMed]

3. Thavasi, R.; Jayalakshmi, S.; Banat, I.M. Application of biosurfactant produced from peanut oil cake by Lactobacillus delbrueckii in biodegradation of crude oil. Bioresour. Technol. 2011, 102, 3366-3372. [CrossRef] [PubMed]

4. Sharma, D.; Saharan, B.S.; Chauhan, N.; Procha, S.; Lal, S. Isolation and functional characterization of novel biosurfactant produced by Enterococcus faecium. SpringerPlus 2015, 4, 1-14. [CrossRef] [PubMed]

5. Banat, I.M. Biosurfactants production and possible uses in microbial enhanced oil recovery and oil pollution remediation: A review. Bioresour. Technol. 1995, 51, 1-12. [CrossRef]

6. Odukkathil, G.; Vasudevan, N. Residues of endosulfan in surface and subsurface agricultural soil and its bioremediation. $J$. Environ. Manag. 2016, 165, 72-80. [CrossRef] 
7. Singh, P.; Saini, H.S.; Raj, M. Rhamnolipid mediated enhanced degradation of chlorpyrifos by bacterial consortium in soil-water system. Ecotoxicol. Environ. Saf. 2016, 134, 156-162. [CrossRef]

8. Wattanaphon, H.T.; Kerdsin, A.; Thammacharoen, C.; Sangvanich, P.; Vangnai, A.S. A biosurfactant from Burkholderia cenocepacia BSP3 and its enhancement of pesticide solubilization. J. Appl. Microbiol. 2008, 105, 416-423. [CrossRef] [PubMed]

9. Mata-Sandoval, J.C.; Karns, J.; Torrents, A. Effect of nutritional and environmental conditions on the production and composition of rhamnolipids by P. aeruginosa UG2. Microbiol. Res. 2001, 155, 249-256. [CrossRef]

10. García-Reyes, S.; Yáñez-Ocampo, G.; Wong-Villarreal, A.; Rajaretinam, R.K.; Thavasimuthu, C.; Patiño, R.; Ortiz-Hernández, M.L. Partial characterization of a biosurfactant extracted from Pseudomonas sp. B0406 that enhances the solubility of pesticides. Environ. Technol. 2018, 39, 2622-2631. [CrossRef]

11. Singh, P.; Sharma, S.; Saini, H.; Chadha, B. Biosurfactant production by Pseudomonas sp. and its role in aqueous phase partitioning and biodegradation of chlorpyrifos. Lett. Appl. Microbiol. 2009, 49, 378-383. [CrossRef]

12. Damalas, C.A.; Eleftherohorinos, I.G. Pesticide exposure, safety issues, and risk assessment indicators. Int. J. Environ. Res. Public Health 2011, 8, 1402-1419. [CrossRef]

13. Ippolito, A.; Fait, G. Pesticides in surface waters: From edge-of-field to global modelling. Curr. Opin. Environ. Sustain. 2019, 36, 78-84. [CrossRef]

14. Karanasios, E.; Karpouzas, D.G.; Tsiropoulos, N.G. Key parameters and practices controlling pesticide degradation efficiency of biobed substrates. J. Environ. Sci. Health Part B 2012, 47, 589-598. [CrossRef]

15. Karas, P.A.; Perruchon, C.; Karanasios, E.; Papadopoulou, E.S.; Manthou, E.; Sitra, S.; Ehaliotis, C.; Karpouzas, D.G. Integrated biodepuration of pesticide-contaminated wastewaters from the fruit-packaging industry using biobeds: Bioaugmentation, risk assessment and optimized management. J. Hazard. Mater. 2016, 320, 635-644. [CrossRef] [PubMed]

16. Gennari, M.; Messina, C.; Abbate, C.; Baglieri, A.; Boursier, C. Solubility and adsorption behaviors of chlorpyriphos-methyl in the presence of surfactants. J. Environ. Sci. Health Part B 2009, 44, 235-240. [CrossRef]

17. Sequinatto, L.; Reichert, J.M.; Dos Santos, D.R.; Reinert, D.J.; Copetti, A.C.C. Occurrence of agrochemicals in surface waters of shallow soils and steep slopes cropped to tobacco. Química Nova 2013, 36, 768-772. [CrossRef]

18. Diez, M.C.; Leiva, B.; Gallardo, F. Novel insights in biopurification system for dissipation of a pesticide mixture in repeated applications. Environ. Sci. Pollut. Res. 2018, 25, 21440-21450. [CrossRef] [PubMed]

19. Tortella, G.R.; Rubilar, O.; Cea, M.; Wulff, C.; Martinez, O.; Diez, M.C. Biostimulation of agricultural biobeds with npk fertilizer on chlorpyrifos degradation to avoid soil and water contamination. J. Soil Sci. Plant Nutr. 2010, 10, 464-475. [CrossRef]

20. Briceño, G.; Lamilla, C.; Leiva, B.; Levio, M.; Donoso-Piñol, P.; Schalchli, H.; Gallardo, F.; Diez, M.C. Pesticide-tolerant bacteria isolated from a biopurification system to remove commonly used pesticides to protect water resources. PLoS ONE 2020, 15, e0234865. [CrossRef]

21. Castillo, M.D.P.; Torstensson, L.; Stenström, J. Biobeds for environmental protection from pesticide use-a review. J. Agric. Food Chem. 2018, 56, 6206-6219. [CrossRef] [PubMed]

22. Diez, M.C.; Elgueta, S.; Rubilar, O.; Tortella, G.R.; Schalchli, H.; Bornhardt, C.; Gallardo, F. Pesticide dissipation and microbial community changes in a biopurification system: Influence of the rhizosphere. Biodegradation 2017, 28, 395-412. [CrossRef]

23. Fernández-Alberti, S.; Rubilar, O.; Tortella, G.R.; Diez, M.C. Chlorpyrifos degradation in a Biomix: Effect of pre-incubation and water holding capacity. J. Soil Sci. Plant Nutr. 2012, 12, 785-799. [CrossRef]

24. Sachdev, D.P.; Cameotra, S.S. Biosurfactants in agriculture. Appl. Microbiol. Biotechnol. 2013, 97, 1005-1016. [CrossRef] [PubMed]

25. Abouseoud, M.; Maachi, R.; Amrane, A.; Boudergua, S.; Nabi, A. Evaluation of different carbon and nitrogen sources in production of biosurfactant by Pseudomonas fluorescens. Desalination 2008, 223, 143-151. [CrossRef]

26. Odukkathil, G.; Vasudevan, N. Enhanced biodegradation of endosulfan and its major metabolite endosulfate by a biosurfactant producing bacterium. J. Environ. Sci. Health Part B 2013, 48, 462-469. [CrossRef]

27. Luna, J.M.; Rufino, R.D.; Sarubbo, L.A.; Campos-Takaki, G.M. Characterisation, surface properties and biological activity of a biosurfactant produced from industrial waste by Candida sphaerica UCP0995 for application in the petroleum industry. Colloids Surf. B Biointerfaces 2013, 102, 202-209. [CrossRef] [PubMed]

28. Rufino, R.D.; Luna, J.M.; Sarubbo, L.A.; Rodrigues, L.R.M.; Teixeira, J.A.C.; Campos-Takaki, G.M. Antimicrobial and anti-adhesive potential of a biosurfactant rufisan produced by Candida lipolytica UCP 0988. Colloids Surf. B Biointerfaces 2011, 84, 1-5. [CrossRef] [PubMed]

29. Rostás, M.; Blassmann, K. Insects had it first: Surfactants as a defence against predators. Proc. R. Soc. B Boil. Sci. 2009, 276, 633-638. [CrossRef]

30. Awashti, N.; Kumar, A.; Makkar, R.C.S. A chlorinated pesticide in presence of biosurfactant. Environ. Sci. Health B 1999, 34, 793-803.

31. Lotfabad, T.B.; Ebadipour, N.; Roostaazad, R.; Partovi, M.; Bahmaei, M. Two schemes for production of biosurfactant from Pseudomonas aeruginosa MR01: Applying residues from soybean oil industry and silica sol-gel immobilized cells. Colloids Surf. B Biointerfaces 2017, 152, 159-168. [CrossRef]

32. Chakraborty, S.; Ghosh, M.; Chakraborti, S.; Jana, S.; Sen, K.K.; Kokare, C.; Zhang, L. Biosurfactant produced from Actinomycetes nocardiopsis A17: Characterization and its biological evaluation. Int. J. Biol. Macromol. 2015, 79, 405-412. [CrossRef]

33. Song, B.; Springer, J. Determination of interfacial tension from the profile of a pendant drop using computer-aided image processing. J. Colloid Interface Sci. 1996, 184, 77-91. [CrossRef] 
34. Abbasi, H.; Sharafi, H.; Alidost, L.; Bodagh, A.; Zahiri, H.; Noghabi, K. Response surface optimization of biosurfactant produced by Pseudomonas aeruginosa MA01 isolated from spoiled apples. Prep. Biochem. Biotechnol. 2013, 43, 398-414. [CrossRef] [PubMed]

35. Jain, R.M.; Mody, K.; Joshi, N.; Mishra, A.; Jha, B. Production and structural characterization of biosurfactant produced by an alkaliphilic bacterium, Klebsiella sp.: Evaluation of different carbon sources. Colloids Surf. B Biointerfaces 2013, 108, 199-204. [CrossRef] [PubMed]

36. Haloi, S.; Sarmah, S.; Gogoi, S.B.; Medhi, T. Characterization of Pseudomonas sp. TMB2 produced rhamnolipids for ex-situ microbial enhanced oil recovery. 3 Biotech 2020, 10, 120. [CrossRef]

37. Pacheco, G.J.; Ciapina, E.M.P.; Gomes, E.D.B.; Pereira, N., Jr. Biosurfactant production by Rhodococcus rythropolis and its application to oil removal. Braz. J. Microbiol. 2010, 41, 685-693. [CrossRef] [PubMed]

38. Thavasi, R.; Nambaru, V.R.M.S.; Jayalakshmi, S.; Balasubramanian, T.; Banat, I.M. Biosurfactant production by Pseudomonas aeruginosa from renewable resources. Indian J. Microbiol. 2011, 51, 30-36. [CrossRef] [PubMed]

39. Rosen, M.J. Emulsification by surfactants. In Surfactants and Interfacial Phenomena; John Wiley and Sons, Inc.: Hoboken, NJ, USA, 2004; pp. 303-331, ISBN 9780471670568.

40. Abouseoud, M.; Maachi, R.; Amrane, A. Biosurfactant production from olive oil by Pseudomonas fluorescens. Commun. Curr. Res. Educ. Top. Trends Appl. Microbiol. 2007, 1, 340-347.

41. Hassen, W.; Neifar, M.; Cherif, H.; Mahjoubi, M.; Souissi, Y.; Raddadi, N.; Fava, F.; Cherif, A. Assessment of genetic diversity and bioremediation potential of pseudomonads isolated from pesticide-contaminated artichoke farm soils. 3 Biotech $2018,8,263$. [CrossRef] [PubMed]

42. Leite, G.G.F.; Figueirôa, J.V.; Almeida, T.C.M.; Valões, J.L.; Marques, W.F.; Duarte, M.D.D.C.; Gorlach-Lira, K. Production of rhamnolipids and diesel oil degradation by bacteria isolated from soil contaminated by petroleum. Biotechnol. Prog. 2016, 32, 262-270. [CrossRef]

43. Nurfarahin, A.H.; Mohamed, M.S.; Phang, L.Y. Culture medium development for microbial-derived surfactants production-an overview. Molecules 2018, 23, 1049. [CrossRef]

44. Viramontes-Ramos, S.; Portillo-Ruiz, M.C.; Ballinas-Casarrubias, M.D.L.; Torres-Muñoz, J.V.; Rivera-Chavira, B.E.; NevárezMoorillón, G.V. Selection of biosurfactan/bioemulsifier-producing bacteria from hydrocarbon-contaminated soil. Braz. J. Microbiol. 2010, 41, 668-675. [CrossRef] [PubMed]

45. Belcher, R.W.; Huynh, K.V.; Hoang, T.V.; Crowley, D.E. Isolation of biosurfactant-producing bacteria from the Rancho La Brea Tar Pits. World J. Microbiol. Biotechnol. 2012, 28, 3261-3267. [CrossRef]

46. Rocha, V.A.L.; de Castilho, L.V.A.; de Castro, R.P.V.; Teixeira, D.B.; Magalhães, A.V.; Gomez, J.G.C.; Freire, D.M.G. Comparison of mono-rhamnolipids and di-rhamnolipids on microbial enhanced oil recovery (MEOR) applications. Biotechnol. Prog. 2020, 36, e2981. [CrossRef] [PubMed]

47. Santos, D.K.F.; Rufino, R.D.; Luna, J.M.; Santos, V.A.; Sarubbo, L.A. Biosurfactants: Multifunctional Biomolecules of the 21st Century. Int. J. Mol. Sci. 2016, 17, 401. [CrossRef] [PubMed]

48. Singh, P.; Tiwary, B.N. Isolation and characterization of glycolipid biosurfactant produced by a Pseudomonas otitidis strain isolated from Chirimiri coal mines, India. Bioresour. Bioprocess. 2016, 3, 42. [CrossRef]

49. Angelini, R.; Babudri, F.; Lobasso, S.; Corcelli, A. MALDI-TOF/MS analysis of Archaebacterial lipids in lyophilized membranes dry-mixed with 9-aminoacridine. J. Lipid Res. 2010, 51, 2818-2825. [CrossRef]

50. Diez, M.C.; Levio, M.; Briceño, G.; Rubilar, O.; Tortella, G.; Gallardo, F. Biochar as a partial replacement of peat in pesticidedegrading biomixtures formulated with different soil types. J. Biobased Mater. Bioenergy 2013, 7, 741-747. [CrossRef]

51. Elgueta, S.; Correa, A.; Campo, M.; Gallardo, F.; Karpouzas, D.; Diez, M.C. Atrazine, chlorpyrifos, and iprodione effect on the biodiversity of bacteria, Actinomycetes, and fungi in a pilot biopurification system with a green cover. J. Environ. Sci. Health Part B 2017, 52, 651-657. [CrossRef]

52. Tortella, G.R.; Rubilar, O.; Castillo, M.D.P.; Cea, M.; Mella-Herrera, R.; Diez, M.C. Chlorpyrifos degradation in a biomixture of biobed at different maturity stages. Chemosphere 2012, 88, 224-228. [CrossRef] [PubMed]

53. Chen, S.; Liu, C.; Peng, C.; Liu, H.; Hu, M.; Zhong, G. Biodegradation of Chlorpyrifos and Its Hydrolysis Product 3,5,6-Trichloro2-Pyridinol by a New Fungal Strain Cladosporium cladosporioides Hu-01. PLoS ONE 2012, 7, e47205. [CrossRef] [PubMed]

54. Chishti, Z.; Hussain, S.; Arshad, K.R.; Khalid, A.; Arshad, M. Microbial degradation of chlorpyrifos in liquid media and soil. J. Environ. Manag. 2013, 114, 372-380. [CrossRef] [PubMed]

55. Briceño, G.; Fuentes, M.S.; Palma, G.; Jorquera, M.A.; Amoroso, M.J.; Diez, M.C. Chlorpyrifos biodegradation and 3,5,6-trichloro2-pyridinol production by Actinobacteria isolated from soil. Int. Biodeterior. Biodegrad. 2012, 73, 1-7. [CrossRef] 